my major intellectual inspiration. I remember how he frequently welcomed me-a lowly and very confused undergraduate-into his office and invariably could produce something he had written on almost any conceivable topic.

People who knew Campbell remember him as much for his humanity as for his intellectual contributions. In spite of his stature, he was known for his humility, for his incredible kindness and caring, and for his tolerance which he demonstrated in all possible ways. He will be greatly missed.

Burt Perrin

Toronto, Ontario, Canada

\section{William S. Hardenbergh}

Bill Hardenbergh died in his 68th year on January 28,1996 , at home. He was Professor Emeritus in the Department of Political Science at Southern Illinois University in Carbondale, Illinois, and served in the department as a popular professor for thirty years. Bill was born on July 10, 1928, in Evanston, Illinois, and earned his B.A., M.A., and Ph.D. at the University of Illinois. He completed his doctoral work in 1954 and taught at the University of Akron until 1960. He then joined the department at SIUC.

Hardenbergh's specialty was comparative politics, with emphasis on the politics of developing areas, South Asia, the Middle East, and Africa. During his career Bill taught at the University of Dacca as a Fulbright Professor and traveled widely and often in East Asia, Africa and the Middle East. In his travels he would touch base with the legions of former graduate students who completed their theses and dissertations under his supervision and are now professors and cabinet ministers around the world.

Bill's contributions to the university and department were enormous. He served as Director of Graduate Studies for many years, contributed to many university committees with his reasoned voice, and served as advisor to a wide variety of foreign student organizations by popular demand, including the university's cricket club. He was the AAUP president on our campus and served on the Executive Committee of the Illinois Conference of the AAUP for several years.

At the campus memorial service conducted on February 1, 1996, all speakers referred to Bill's dedication to students, his integrity, and his tenacity in representing the basic principles which are the foundation of all academic communities.

Bill Hardenbergh represented the classical values of the teacher scholar; he loved teaching; and he was very good at his profession. He was an eminently fair, humane person who tackled complicated issues with a clear mind and without jargon.

Bill continued to work with his graduate students into retirement. We miss him. A Hardenbergh International Relations Scholarship Fund was established at the SIUC Foundation to honor his legacy.

\section{Manfred Landecker \\ Southern Illinois University at Carbondale}

\section{James L. McCamy}

James L. McCamy, Professor Emeritus of Political Science died on December 14, 1995. He was 89 years old. His wife Julia passed on earlier in the year. He is survived by his sons Colin and Keith.

Jim's career combined teaching, research, and high level government service. He taught at Bennington College from 1934 to 1939 and received his Ph.D. from the University of Chicago in 1938 . He then joined the federal government, serving first as assistant to Henry Wallace in the Department of Agriculture. He later served in various positions concerned with wartime and postwar foreign economic policy. He took part in the administration of the lend lease program and postwar reconstruction funding in Europe and he was one of the authors of the charter of the International Trade Organization. He served in the occupation administration in Austria. He joined the University of Wisconsin faculty in 1947 and taught here continuously until his retirement in 1971.
Jim's research and teaching interests grew out of his government service. He taught and wrote about public administration and the conduct of American foreign policy throughout his career. In addition, while at Wisconsin, he developed a special interest in science and public policy which was the focus of much of his creative intellectual work at the height of his career. He was the author of three major scholarly works, The Administration of American Foreign Affairs (1950), Science and Public Administration (1960), and Conduct of the New Diplomacy (1964). He also wrote an American government textbook (1957) and two studies of government publicity and publications.

McCamy had passionate convictions about government and public service. His approach to political science reflected the spirit of an age that had more faith than ours in the positive and creative role that government could play in human affairs. Jim was fascinated by the big issues of public policy. He cared about the conduct of government. He wanted it to be well organized and democratically responsive to the concerns of the people. He taught that public service was one of the most honorable of callings and that it required not only competence and responsibility but broad vision and intellectual imagination as well.

He was particularly interested in the problems raised for public policy by scientific advance. He was optimistic about the promise of science but realized that the benefits came with a darker side of risks and problems that required social control. Long before Eisenhower's dramatic farewell address warned of a military-industrial and science complex, Jim was writing about the dilemma of dependence on scientific experts in policy decisions. He knew from experience that such experts had no special insight into public affairs, however much their expertise was necessary in policy making. He thought broadly and creatively about the fundamental issues of nuclear power, medical ethics, and he was one of the pio- 